\title{
Historical importance of District Rajanpur
}

\author{
Sohail Akhtar* and Azhar Maqsood \\ Lecturer in History, Ghazi University, Pakistan \\ *Corresponding author: Sohail Akhtar, Lecturer in History, Ghazi University, Pakistan
}

Submission: 監June 27, 2018 ; Published: 監 August 27, 2018

\begin{abstract}
Rajanpur District is the most southern District of Punjab at this time. It was formed as a new District in 1982 with along with the formation of Division Dera Ghazi Khan. The town was established by Makhdoom Syed Rajan Shah, Rajan Pur has seen lot of ups and down in the history from earlier time to till now. It is an important geographical location due to adjoining boundary with Balochistan and Sindh. It was also a trade route in the past. The famous ancient fort Harand is also located in the district. This research Paper high lights the historical importance of the district Rajanpur.
\end{abstract}

Keywords: Rajanpur district; Punjab; Pakistan; Harand; Dajal

\section{Introduction}

District Rajanpur is located at the extreme south of Punjab province. This district is a junction of three provinces i.e. Punjab, Sindh and Balochistan. It is located at 29.06 in north and 70.19 in east. Total area of the district is 12,318 square kilometers. According to the census report of 1998 , the total population is $1,103,618$. The total Number of males are 580822 which are $52.63 \%$ of the total population. Females are 522796 comprising $47.37 \%$ of the total population of the District. Sex ratio is 111.1 males against 100 females. Population density is 89.6 per square kilometer. The annual growth rate is 2.4 percent in District Rajanpur.

History is silent about the local people dwelling here for centuries. As we have said this region was the pathway of the conquerors. So amalgamation of races is very much possible. Various Baloch tribes and castes claim different origins of their race. It is thought that Baloch race is a combination of Aryans, Arabs and local people of ancient Balochistan. Iranian conquerors stretched their boundaries in east to Indus Valley in 522 to 486 B.C and this region was also in their custody. In third century B.C, when Ashoka the great became viceroy of Texila, he was governing the whole area from Taxila to Balochistan. This shows that Texila was the capital of this region. After embracing Islam, Arab conquerors invaded new regions of the world during the reign of Hazrat Umar (R.A). Mohlab attacked Makran in 44 Hijri but failed to conquer it. Muhammad Bin Qasim attacked Sindh in 712 A.D. Then he conquered Multan and appointed Akrama Bin Rehan Shami as the Governor of Multan province. He was the first Arab Governor of Multan and this sequence sustained till the reign of Caliph Haroon Rashid. After Arabs, Karamtian took over as the rulers of Multan in 367 Hijri, Sabuktagin of Ghazna defeated Karamtian army and appointed Sheikh Hameed as the Governor of Multan. Karamtian took over again and Sabuktagin's son Mehmood of Ghazna attacked Multan in 1006 A.D but Daud bin Nasr resisted and the attack was failed. Four years later, Mehmood conquered Multan and massacred the people of Multan. Ghazi Khan Meerani conquered Dajal and Harand in 1469 and after while built a new city Dera Ghazi Khan after his name. Rule of Meeran is was ended in 1767 by Mehmood Khan Gujar. King of Khurasan was the ruler of this region at that time and Meerani Governors associated themselves with the throne of Khurasan. Mehmood Khan Gujar continued his obedience with Khurasan Dynasty. Historically, this region had been a part of Multan province. They were few and far occasions when this region was associated with Khurasan, Seestan or any other state. In 1806, Sikh army attacked Multan but because of the resistance of Nawab Muzafar Khan they could not succeed. In 1818 Maharaja Ranjeet Singh finally conquered Multan and after three years he appointed Dewan Sawan Mall as the Governor of Multan. After the death of Dewan Sawan Mall, His son Mooleraj was appointed as the Governor of Multan. He was the last Governor in Sikh reign.

\section{History in British Era}

According to official record of British Government, the city of Multan was conquered in 1846 by General Courtland. Since that day the entire region remained under the custody of British Government till 1947. Molraj, the Governor of Multan resisted bravely. After being defeated, he managed to escape but after a while he submitted and was detained by the government. He died in the jail. Courtland was appointed as Deputy Commissioner Dera Ghazi Khan as Multan was given the status of Divisional Headquarter and Dera Ghazi Khan was a district of Multan division. There four 
Tehsils of District Dera Ghazi Khan i.e., Dera Ghazi Khan, Sanghar, Dajal and Kot Mithon. In 1855, Rajanpur was declared Assistant Residency. Seven years later, Kot Mithon was flooded and Rajanpur became Tehsil Headquarter of District Dera Ghazi Khan. In 1865, Jampur was declared a Tehsil instead of Dajal. In 1866, Robert Sandeman was appointed as Deputy Commissioner Dera Ghazi Khan. He introduced "Tumandara" System and divided the whole district into the nine "Tumans". Three Tumans, Mazari, Darishsak and Gorchani lie in the area of District Rajanpur. During English Regime these Tumandar enjoyed social, economical and political monopoly being a loyal of British Government.

Pakistan came into being on August 14, 9147. Unfortunately, the political role of feudal prevailed and they continued to enjoy their status. Unjust and dictatorial policies resulted in the demise of East Pakistan in 1971. Even after this disaster no heed was paid to the aspirations of the people. In 1982, General Zia ul Haq declared Dera Ghazi Khan as a new Divisional Headquarter and Rajanpur became a district of Dera Ghazi Khan Division. District Rajanpur has four Tehsils which are Rajanpur, Jampur and Rojhan. But this area has been kept backward. Rajanpur is the most deprived and underdeveloped district of Punjab. Rajanpur city is the Headquarter of district Rajanpur. Its distance from Islamabad is 746 kilometers, from Lahore 472 kilometers and from Dera Ghazi Khan 115 kilometers. Rajanpur had been a Tehsil Headquarter of District Dera Ghazi khan along with three other Tehsil. General Zia-uallhaq announced the status of district for Rajanpur in 1982. It is an old city. Sheikh Rajan Bakhsh Makhdoom, the ruler of Saitpur, built Rajanpur city in $1145 \mathrm{Hijri}$. Another view about the name of the city that Aryans used the title "Rajan" for their rulers some 1500 years ago. Name of the city Rajanpur means city of rulers and is derived from Rajanpur. It was given the status of Assistant Residency of Deputy Commissioner Dera Ghazi Khan. But still Rajanpur city was not considered an important place because Kot Mithan already had the status of Tehsil and Kot Mithon was very near to Rajanpur. In 1862, Kot Mithon was flooded and all the government offices were shifted to Rajanpur, and Rajanpur was given the status of a Tehsil of district Dera Ghazi Khan. Although Rajanpur city has the status of district, headquarter.

It is still, not the most populated and the biggest city in the district. So Punjab Government was seriously thinking to shift the district head quarter to Jampur. Moreover, the place was thought to be deprived of the status of Tehsil and Kot Mithon was suggested to get the status of a new Tehsil, in 2009-10. At that time, Ghazi Aman Ullah was the District Co-ordination Officer (DCO), Rajanpur. He disagreed with the plan and started re-building of Rajanpur city. He built new roads, government offices, parks and new buildings for colleges, hospitals and district jail, Rajanpur. His efforts proved fruitful and the authorities changed their mind about shifting the Headquarter. Now Rajanpur city is relatively small but a clean and urbanized place. Its greenery and cleanliness are impressive. A cemented canal can be seen passing through the centre of the city which enhances the beauty of Rajanpur. The population of the city is 48505 souls. Its area is 6 square kilometers. It has become the head quarter of Dareshak tribe. No doubt, Rajanpur is a worth visiting place now.

Mari is a visiting Place 100 kilometers away from Rajanpur city. It is a hill station in mountain range of Koh Suleman in Tehsil Rojhan. Mari is, probably the coolest place in the District. The population of this place is 25,247 . In history, Mari was a very important place. In Saraiki language, Mari means a double storied building. It is said that Sar Kup built a palace for his daughter. Because of this, the place was named "Mari Koklan". Later the name remained Mari. People here are very poor. They are living from hand to mouth. The number of people visiting Mari can be increased many fold by building infrastructure. The road leading to Mari is in very poor condition. So access there is quit hard. Second problem is lack of facilities. Availability of water is a serious problem. Residence and shops for buying commodities are very few and far. There is no public park and library. If these facilities are provided, it can be converted into a worth visiting place. Harand is the oldest city in the whole region. According to ancient Hindu Shastra, "It is said that Harondo Pawan, the king of Delhi built this city and its name Harand is after the name of the king. This city is across the river (Indus) and city is famous for its dance." Hutu Ram writes, when king Hamayun went to Dehli, Meer Chaker accompanied him in 1540. They passed through this region. On that time, Afghan tribes were in Harand. Gorchani tribe attacked Harand fort and defeated Afghans". This famous Harand fort was one of the most difficult forts to conquer. With the passage of time, the Fort of Harand and its population were ruined and now ruins of Harand fort can be seen 86 kilometers from Rajanpur city and no population can be found. Harand is in Tehsil Rojhan and it is declared National Heritage.
Creative Commons Attribution 4.0 International License

For possible submissions Click Here

\section{Submit Article}

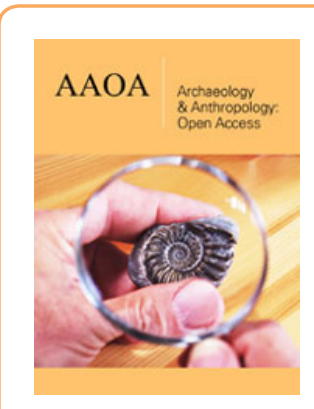

Archaeology \& Anthropology: Open Access

\section{Benefits of Publishing with us}

- High-level peer review and editorial services

- Freely accessible online immediately upon publication

- Authors retain the copyright to their work

- Licensing it under a Creative Commons license

- Visibility through different online platforms 